\title{
The characteristics of the infection of juvenile Atlantic salmon with glochidia of the freshwater pearl mussel in rivers of Northwest Russia
}

\author{
E.P. Ieshko ${ }^{1}$, J. Geist ${ }^{2}$, S.A. Murzina ${ }^{1, \star}$, A.E. Veselov ${ }^{1}$, D.I. Lebedeva ${ }^{1}$ and V.V. Ziuganov ${ }^{3}$ \\ 1 Institute of Biology, Karelian Research Centre, Russian Academy of Sciences, Pushkinskaya street, 11, Petrozavodsk 185910, Russia \\ 2 Aquatic Systems Biology Unit, Technische Universitaet Muenchen, Germany \\ 3 Koltsov Institute of Developmental Biology, Russian Academy of Sciences, Russia
}

Received March 23, 2015 - Revised November 5, 2015 - Accepted November 10, 2015

\begin{abstract}
The decline of freshwater pearl mussel (Margaritifera margaritifera L.) populations is globally well documented, but there is a lack of knowledge concerning the status of the species and its interaction with host fishes in the rivers of the White and Baltic Seas. This study aimed to identify the host fish of pearl mussel in four rivers of Karelia (Northwest Russia), to analyse the duration of the parasitic phase, and the susceptibility of fish hosts to the infestation. Juvenile sea-migrating and land-locked Atlantic salmon (Salmo salar L.) were identified as the most important hosts. In the Keret' River, reduced numbers of juvenile Atlantic salmon are likely to result in a decline of pearl mussel. This problem does not appear to be present for the other three studied rivers. Pearl mussel glochidia were mostly found in yearlings $(0+)$, whereas older fish were infected less, suggesting a more complex pattern of host use than commonly expected. The remote location of Karelian pearl mussel rivers, the high number of pearl mussels in them, and their rather pristine state all suggest that these rivers have a high conservation priority. The importance of Atlantic salmon as a host fish and the emerging declines of Atlantic salmon populations, e.g., in the Keret' River, suggest that the sustaining of this host species should have a high conservation priority.
\end{abstract}

Key-words: Margaritifera margaritifera / Salmo salar / glochidial infestation / host fish

Résumé - Les caractéristiques de l'infestation de saumons atlantiques juvéniles par des glochidies de la moule perlière d'eau douce dans les rivières de la Russie du Nord-Ouest. Le déclin des populations de la moule perlière (Margaritifera margaritifera L.) est globalement bien documenté, mais il y a un manque de connaissances concernant le statut de l'espèce et son interaction avec les poissons hôtes dans les rivières des mers Blanche et Baltique. Cette étude visait à identifier les poissons hôtes de la moule perlière dans quatre rivières de la Carélie (Ouest de la Russie), pour analyser la durée de la phase parasitaire, et la sensibilité des poissons hôtes à l'infestation. Les juvéniles de saumon atlantique migrants ou land-locked (Salmo salar L.) ont été identifiés comme les hôtes les plus importants. Dans la rivière Keret', la réduction du nombre de saumons atlantiques juvéniles est susceptible d'entraîner une baisse de la moule perlière. Ce problème ne semble pas être présent pour les trois autres rivières étudiées. Les glochidies de moule perlière ont été principalement trouvés dans les poissons de l'année $(0+)$, tandis que les poissons plus âgés ont été moins infectés, ce qui suggère un modèle de l'utilisation des hôtes plus complexe que généralement prévu. L'éloignement des rivières de Carélie à moules perlières, le nombre élevé de moules perlières présentes, leur état plutôt vierge suggèrent que ces rivières ont une haute priorité de conservation. L'importance du saumon atlantique comme poisson hôte et les baisses en cours des populations de saumon de l'Atlantique, par exemple, dans la rivière Keret', suggère que le maintien de cette espèce hôte doit avoir une haute priorité de conservation.

Mots-clés : Margaritifera margaritifera / Salmo salar / infestation glochidiale / poisson hôte

\section{Introduction}

The freshwater pearl mussel (Margaritifera margaritifera L.) is a threatened species of the European fauna. Its conservation status is secured by Annex III of the Bern Convention

\footnotetext{
^ Corresponding author: murzina.svetlana@gmail.com
}

(1979) and the IUCN Red List of Threatened Animals (1996), as well as the Red Data Book of East Fennoscandia (1998), the Red Data Book of the Russian Federation (2001) and the Red Data Book of Karelia (2007). A unique feature of this mussel is the exceptionally long life span, sometimes exceeding 200 years (Bauer, 1992). 
The freshwater pearl mussel has a complex life cycle with an obligate parasitic phase on a salmonid fish host. The hostparasite relationship is exceptional in the way that the generation intervals and life span of the host are far shorter than the generation time of the parasite (Geist and Kuehn, 2008). The mussel larvae (glochidia) must encyst on the gills of salmonids to develop, with juveniles being the preferred hosts. Glochidia attach themselves to gill filaments and become encapsulated in a cyst formed by the host (Young and Williams, 1984; Bauer, 1987; Ziuganov et al., 1994). This phase of larval development involves metamorphosis and a transfer of nutrients from the host to the mussel (Taeubert et al., 2015). It begins in autumn and is completed the following summer. In summer, young mussels leave the host to live freely. Some authors argue that the mussels are the most vulnerable during this life phase, which lasts approximately 5 years (Hastie and Young, 2001; Geist and Auerswald, 2007; Geist, 2010).

Most researchers believe that the parasitic larval phase does not limit recruitment and thus does not play a significant role in maintaining the numbers of the pearl mussel. The focus is usually on the hosts on which the glochidia specialize - Atlantic salmon and brown trout - as well as on the response of the host to the infection (Young and Williams, 1984; Bauer, 1987; Geist et al., 2006). There is also no agreement on how pathogenic the glochidia are while residing on juvenile salmonids (Cunjak and McGladdery, 1991). Because high loads of pearl mussel glochidia typically result in reduced swimming performance and increased mortality of brown trout hosts, and because there is a transfer of nutrients from the fish to the mussel involved, the relationship is considered parasitic (Taeubert and Geist, 2013; Taeubert et al., 2015). Most studies only measure the total glochidial loads on a fish host without considering the distribution of the glochidia.

The metamorphosis of the glochidium of different species of freshwater mussels on the gills of a host fish has been widely studied using histological techniques, and such research provides important information about the host-parasite relationship on a cellular and immunological level. This information can, thus, help answer one of the currently unresolved questions, namely, the host response to attached glochidia (Nezlin et al., 1994; Araujo et al., 2002). Moreover, histology could be used as an instrument to study the growth and general development of glochidia in relationship to host specificity and sustainability and as a means of investigating host suitability, as applied in this study.

Ieshko et al. (2009) presented the first attempt to quantitative analyse and model the population dynamics of glochidia on the gills of juvenile salmon from the Gridina River (Karelia, Russia) and trout from the Skjellbekken River (Norway). In particular, the frequency distribution of parasites among hosts was used as the basis of the quantitative assessment of the nature of parasitism and its role in sustaining ecological system stability (Crofton, 1971a, b).

The core objective of this paper was to identify the host fish of pearl mussel in four rivers of Karelia (Northwest Russia) and to analyse the duration of the parasitic phase as well as the susceptibility of fish hosts to the infestation. This included analysing the distribution patterns and abundances of freshwater pearl mussel glochidia on the gills of juvenile land-locked and anadromous Atlantic salmon from rivers of Karelia, and the characterisation of the size- and age-dependency of the infestation. Additionally, the aggregation patterns of glochidial distribution depending on the timing of salmon parr infestation in the rivers were considered, as well as the stage of metamorphosis of the pearl mussel larvae.

Specifically, we hypothesize that (i) Atlantic salmon is the preferred host in these Northern Rivers, (ii) the young of the year fish (YOY) are the most important hosts, and (iii) that glochidial aggregation on the gills is positively linked to glochidial loads.

Although the biology of the freshwater pearl mussel is well described (e.g., Geist, 2010 and references therein), little is known about the populations and their host-dependence in the remote rivers draining into the White, Baltic and Barents Sea, which are believed to harbour some of the largest pearl mussel populations in the world (Ziuganov et al., 1994) and may thus play a crucial role in the conservation of the species in Northwestern Russia.

\section{Materials and methods}

\subsection{Study area}

Four Karelian rivers draining into the White Sea (Rivers Gridina, Keret' and Vuokinjoki) and the Baltic Sea (Syskyänjoki River) with large populations of the freshwater pearl mussel were included in this study (Figure 1). All of these rivers provide the rare opportunity of studying the pearl mussel host-parasite relationship in its pristine state since all of the rivers are located in remote areas with their catchments being entirely unaffected by agricultural land use, catchment management or frequent fish stockings.

The Gridina River is $72 \mathrm{~km}$ long and the main channel includes 24 major rapids. Sea-migrating Atlantic salmon spawn in the river. The drainage area is $468.2 \mathrm{~km}^{2}$. The population of young salmon include different age classes $(0+, 1+, 2+)$ varying among habitats. Occasional mussels are found in rapids, and small colonies occur downstream of rapids.

The Keret' River is a large Karelian river with no hydropower facilities. Its length from source to mouth is $110 \mathrm{~km}$, including $34 \mathrm{~km}$ of lake-like stretches with stagnant water. The size of the drainage area is $3393 \mathrm{~km}^{2}$. The river flows across 4 large lakes and numerous pools. Atlantic salmon from the White Sea migrate to the river for spawning. As estimated by Ziuganov et al. (1994), pearl mussel abundance in the Keret' used to be over 2 million individuals.

The Vuokinjoki River is $9.2 \mathrm{~km}$ long and empties into Lake Kuito. Land-locked salmon spawn in 5 rapids of the river with a combined length of $2.2 \mathrm{~km}$. Pearl mussels occur in all rapids. The mussel lives in colonies in some parts of rapids.

The Syskyänjoki River is $33 \mathrm{~km}$ long. The drainage area is $477 \mathrm{~km}^{2}$. The main channel has 4 rapids. Salmon parr densities in this river are high only in the rapid in the headwaters. Land-locked salmon from Lake Ladoga spawn in the river. Densities in the most fast-flowing part of the rapid (surface flow velocities of $1.5-1.7 \mathrm{~m} \cdot \mathrm{s}^{-1}$ ) with the coarse boulder substrate can be high. The densities in the riffles downstream of the rapid, are usually much lower. Pearl mussels inhabit all 


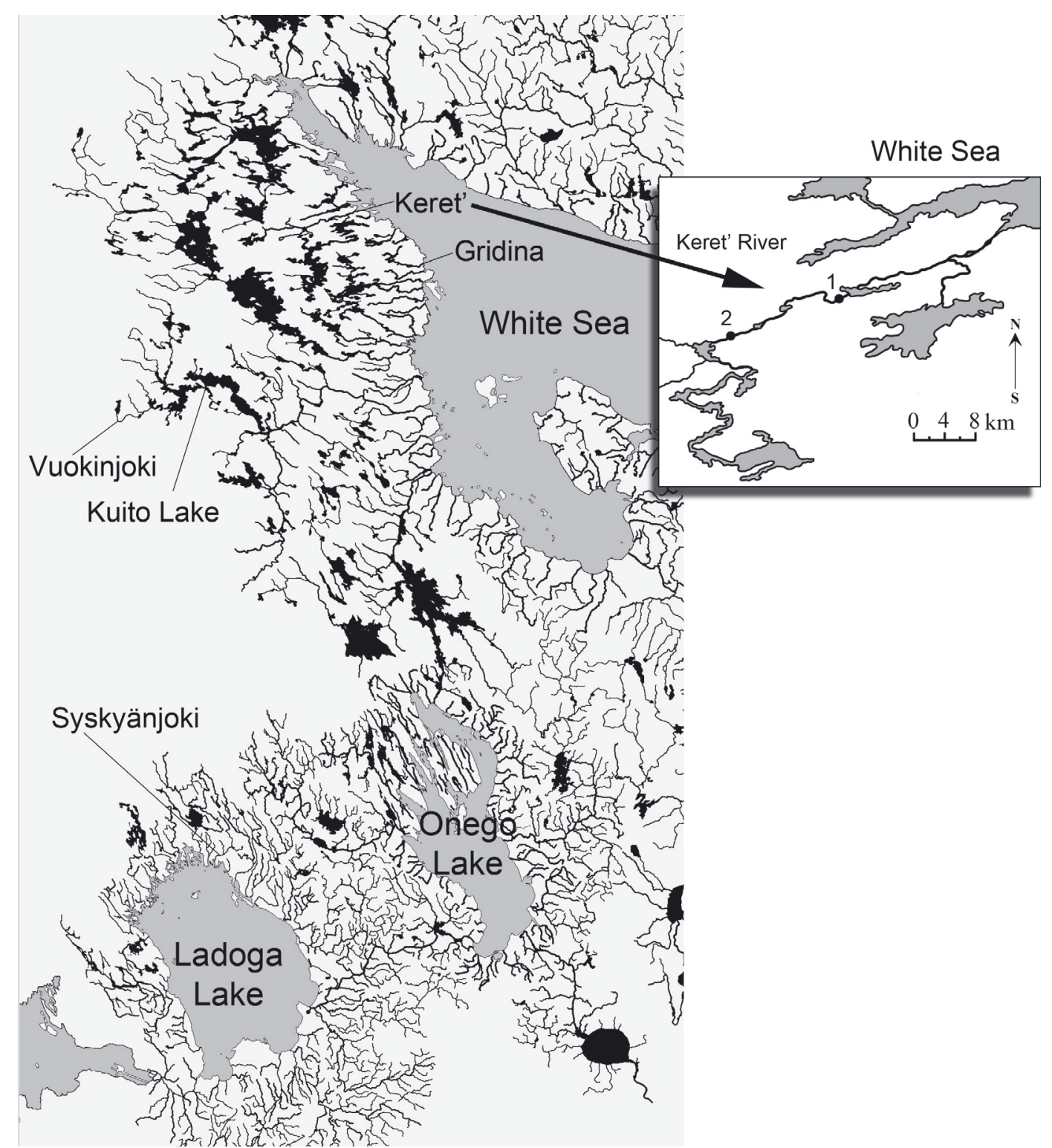

Fig. 1. Locations of studied rivers. Figure 1. Locations of studied rivers. Detailed map of the Keret' River, Sampling sites: 1 - Varatskiy rapid, 2 - Sukhoi rapid.

rapids and riffles from source to mouth. There are both singular mussels and small colonies.

\subsection{Fish sampling and infestation analyses}

Juvenile sea-migrating salmon were captured from rivers Gridina (39 fish) and Keret' (53 fish). Additionally, one adult Atlantic salmon (Salmo salar. Linnaeus, 1758) and àn introduced pink salmon (Oncorhynchus gorbuscha, Walbaum, 1792) from the Gridina River were examined for glochidial infection. The sample from the Vuokinjoki River, which empties into Lake Kuito (Kem' River catchment, White Sea), included 21 specimens of land-locked salmon. In the Baltic Sea drainage basin, juvenile land-locked salmon was sampled from the Syskyänjoki River which drains into Lake Ladoga, with 51 parr studied in different years (Table 1). Fish were captured
Table 1. Population density of juvenile Atlantic salmon and freshwater pearl mussel (FPM) in studied rivers.

\begin{tabular}{|l|c|c|}
\hline Rivers & $\begin{array}{c}\text { Salmon parr } \\
\text { (ind./100 } \mathrm{m}^{2} \text { ) }\end{array}$ & $\begin{array}{c}\text { FPM } \\
\text { (ind./ } \mathrm{m}^{2} \text { ) }\end{array}$ \\
\hline Gridina & $12-98$ & $15-19$ \\
Keret & $4-12$ & $1-30$ \\
Vuokinjoki & $15-36$ & $6-12$ \\
Syskyänjoki & $22-179$ & 20 \\
\hline
\end{tabular}

by electrofishing (Fa-2, Norway), the population density of juveniles Atlantic salmon inhabited rifts of the studied rivers were also evaluated using this method. Density calculations followed the catch-and-release method of Zippin (1956) and Bohlin (1984). 
The distribution and numbers of glochidia on host fish gills from four rivers were studied by partial parasitological dissection (Bykhovskaya-Pavlovskaya, 1985). The infection of the parr was studied on a number of years (2007-2014) in October, when the water temperature below $10{ }^{\circ} \mathrm{C}$. Altogether, 164 parr were measured for weight $( \pm 0.1 \mathrm{~g})$ and total length $\mathrm{AB}( \pm 0.1 \mathrm{~cm})$. The age of fish was determined by counting of annuli from scales posterior to the dorsal fin.

The infestation was quantified using the following indices:

1. Prevalence $(E)$ or percentage of the infected population $(\%)$.

$$
E=\left(N_{i} \times 100\right) / N,
$$

where $N_{i}$ is the number of infected fish, $N$ - number of examined fish.

2. Mean infection intensity (parasites per fish), or index of abundance $(M)$

$$
M=\sum n / N
$$

where $N$ is the number of examined fish, and $\sum n$ is the total number of parasites detected on all examined fish.

Quantitative data were treated (E, M, D computations), the type of the frequency negative binominal distribution law of glochidial numbers was determined, and parameter $k$ was estimated using Quantitative Parasitology (QP) software (Rozsa et al., 2000). Typically, parasitic systems are highly aggregated: most hosts are infected with relatively few parasites, and a small number of hosts are infected with high intensity. Also, the variance of parasite abundance is typically much greater than its mean. Many authors (Crofton, 1971a,b; Anderson et al., 1978; Grafena and Woolhouse, 1993, etc.) stressed that the distribution of parasites in a host population most often conforms to the negative binomial (NB) law, and our previous studies have corroborated this statement (Pavlov and Ieshko, 1986; Ieshko et al., 2009). Negative binomial distribution has two characteristic parameters: mean parasite abundance $(M)$ and parameter $(k)$. Parameter $k$ is inversely proportionate to the degree of parasite aggregation $(k \rightarrow 0$ as parasites are concentrated on a decreasing number of hosts, and $k \rightarrow \infty$ as the distribution grows more even). Using $k$ as a measure of aggregation, one finds aggregation is by far the predominant pattern across natural host-parasite systems (Anderson, 1982; Shaw and Dobson, 1995). Statistical analysis of Pearson correlation between the infection intensity and the infected salmon parr body weight was carried out with the PAST v. 2.17 software (Hammer et al., 2001).

\subsection{Histological analysis}

Material for histological analysis was collected in October, December in 2013 and in May in 2014. Gills of Atlantic salmon parr from the Vuokinjoki River and Syskyänjoki River were dissected from fresh material, fixed in $10 \%$ formaldehyde and subsequently analysed at the environmental biochemistry laboratory of the Institute of Biology of the Karelian Research Centre of the Russian Academy of Sciences (Petrozavodsk, Russia). For this part of the study, we used recommendations and advice from Mikodina et al. (2009).
Tissues were filled with Biodeck R for $24 \mathrm{~h}$, then rinsed during $1 \mathrm{~h}$ with tap water and finally embedded in paraffin using MICROM STP-120 spin tissue processor (Thermo fisher scientific, USA). To make paraffin moulds of dehydrated and paraffin infiltrated tissues, MICROM paraffin embedding centre EC-350 (Thermo fisher scientific, USA) was used. The paraffin moulds were cut on a sliding microtome MICROM HM 450 (Thermo fisher scientific, USA) in transverse sections at $6 \mu \mathrm{m}$ thickness. The sections were stained with haematoxylin and eosin (H\&E) using manual stating containers line (BioOptica, Italy). Histological sections were studied under the light microscope Axioskop 40 (Carl Zeiss) with eye lens $\times 10$ and objective lenses $\times 5, \times 10, \times 20, \times 40, \times 100$. The sections on the slides were photographed with a Pixera Pro 150ES camera connected to the microscope.

All photos were analyzed with Videotest software (VideoTest Ltd, Russia); every glochidia and cyst were measured $( \pm 1 \mu \mathrm{m})$ per microscopic field and the width, length, and diameter in 2D were obtained. Diameter was recommended to measure structures close to an oval according Vidoetest. Diameter $(\mu \mathrm{m})$ was used as a parameter characterized the size and indicating growth progress of glochidia.

\section{Results}

Atlantic salmon (Salmo salmo) parr collected with electrofishing were dominant in the rapids and riffles of the studied rivers. Brown trout (Salmo trutta) were rather uncommon and were not found adjacent to the pearl mussel populations. Data on the abundance of juvenile Atlantic salmon and freshwater pearl mussel in the studied rivers are shown in Table 1.

\subsection{The Gridina River (White Sea drainage basin)}

Early (04th) October surveys revealed a fairly high occurrence of pearl mussel glochidia in juvenile salmon (aged $0+, 1+, 2+$ ) from this river. The survey was conducted at almost the same time at which adult mussels released glochidia in the water. Some glochidia had just attached to the gills of the juvenile fish and were not yet encysted. The mean intensity of the infection was 116.8 glochidia per fish, the prevalence was $84.6 \%$ (Table 2). Young-of-the-year (YOY, 0+) had lower infection parameters compared with older parr $(1+$ and $2+)$. This distinction was more evident for the mean infection intensity -47.4 and 170.5 , respectively (Table 2). However, the mean differences were not significant because this type of distribution is distinctly aggregated. In any case, glochidial abundances in all age classes were modelled by the negative binomial distribution (NBD) (Kolmogorov-Smirnov test 0.36, $p>0.05$, no significant difference at $95.0 \%$ confidence level). Parameter $k$ of the NBD, which describes the degree of aggregation of the parasite on the gills of the examined fish, ranged from 0.272 to 0.342 (Table 2).

In spite of the high aggregation, the positive correlation between parr body weight and the number of glochidia on the parr was only weak (Spearman's $r s=0.33, p<0.04$ ). The linear regression equation has the form: number of glochidia $(N)=18.66+11.33 \times$ fish body weight $(\mathrm{W}), 95.0 \%$ confidence level. 
Table 2. Infection indices and parameters of the negative binomial distribution of glochidial abundances on juvenile Atlantic salmon from rivers of Karelia.

\begin{tabular}{|c|c|c|c|c|c|c|c|}
\hline $\begin{array}{l}\text { River, } \\
\text { sampling site* }\end{array}$ & Year & No of hosts & Infected & Prevalence & \begin{tabular}{|c|} 
Mean \\
abundance
\end{tabular} & Variance, D & $\begin{array}{c}\text { NBD } \\
\text { parameter } k\end{array}$ \\
\hline Gridina (all fish) & 04.10 .2007 & 39 & 33 & 84.6 & 116.8 & 59432.4 & 0.3 \\
\hline YOY 0+ & & 17 & 13 & 76.5 & 47.4 & 13032.5 & 0.3 \\
\hline $1+/ 2+$ juveniles & & 22 & 20 & 90.9 & 170.5 & 90689.6 & 0.3 \\
\hline $\begin{array}{l}\text { Keret'Varatskiy } \\
\text { (all fish) }\end{array}$ & 09.10 .2008 & 21 & 21 & 100.0 & 68.4 & 6246.9 & 0.9 \\
\hline YOY & & 15 & 15 & 100.0 & 39.9 & 1103.8 & 1.4 \\
\hline Syskyänjoki & 26.10.2009 & 15 & 15 & 100.0 & 382.3 & 277783.0 & 1.3 \\
\hline \multirow[t]{3}{*}{ Syskyänjoki } & 08.10 .2013 & 23 & 23 & 100.0 & 10.5 & 89.9 & 1.4 \\
\hline & 05.12 .2013 & 5 & 5 & 5 of 5 & 145,6 & & \\
\hline & 07.05.2014 & 8 & 6 & 6 of 8 & 165,4 & & \\
\hline Vuokinjoki & 17.10 .2013 & 21 & 13 & 61.9 & 48.6 & 6564.9 & 0.2 \\
\hline
\end{tabular}

*Specific site details are confidential owing to threat of illegal pearl fishing.

\subsection{The Keret' River (White Sea drainage basin)}

Early in October 2008, we found pearl mussel larvae on salmon parr from the Keret' (Table 2). All fish were infected, with a mean intensity of 68.4 (ranging from 2 to 317 ) glochidia per fish. The fish sample consisted of YOY and juveniles at age $1+$ (Table 2). The parameters of the glochidial infection in this age class were similar to those in fish from the Gridina River (Table 2). However, parameter $k$ of the abundance NBD was higher (for the entire fish sample, as well as only considering YOY). Fish from the Keret' generally revealed a relatively high and statistically significant correlation (Spearman's $r s=0.70 ; p<0.05)$ between the glochidial abundance and the weight parameters of the fish of different ages. The equation of the linear regression is $N=25.14+8.72 \times W$ (95.0\% confidence level).

\subsection{The Vuokinjoki River (White Sea drainage basin)}

The land-locked salmon parr sample from the river comprised all major age classes, from YOY to $3+$. Generally, glochidial infestation on fish was low (Table 2), with glochidia only detected on 13 fish. The infected fish were mostly YOY, with only 2 specimens aged $1+$. The intensity of infection ranged from 1 to 276 glochidia. Negative correlations were found between the infection intensity (glochidial abundance) and the parr weight (Spearman's $r s=0.41 ; p>0.05$, no statistically significant relationship between $\mathrm{N}$ and $\mathrm{W}$ at the $95.0 \%$ confidence level). Parameter $k$ of the NBD, which describes the degree of aggregation of the parasite on the gills of the examined fish, was the lowest for any studied population in the entire fish sample (Table 2).

\subsection{The Syskyänjoki River (Baltic Sea drainage basin)}

The salmon parr population surveyed late in October 2009 had a high mean abundance (Table 2). The sample from this river comprised mainly older parr $(1+$ and $2+)$ and one dwarf male (5+). Glochidial infection intensity and the fish weight were positively correlated (Spearman's $r s=0.58 p<0.03$ ). The equation of the linear model regression is $N=97.18+$ $47.9 \times W(95.0 \%$ confidence level $)$. Even after exclusion of the $3+$ and $5+$ individuals, which were infected with high numbers of glochidia (318 and 2168, respectively), there was still a positive correlation between the glochidia abundance and the fish weight (Spearman's $r s=0.58, p<0.05$ ).

In 2013, salmon parr in the Syskyänjoki River were also surveyed in October, but the survey was conducted 18 days earlier than the survey in the Vuokinjoki. The sample comprised all age classes from $0+$ to $3+$, but the mean abundance of glochidia was strikingly low (Table 2). A majority of infected fish contained 1 to 10 glochidia, with a maximum individual infection of 31 glochidia per fish. Additionally, we did not find any statistically significant correlation between the number of glochidia and the weight parameters of the infected fish (Spearman's $r s=0.39, p<0.05$ there is no significant relationship between $N$ and $W$ at the 95,0\% confidence level).

The infestation of juvenile fish in the Syskyänjoki River was highly variable in different years and was different by both the values of the mean infection intensities and the distribution of glochidia in the host populations (Kolmogorov-Smirnov statistics $=301$ and $p<0.001$ defined statistically significant differences between the two distributions at the $950 \%$ confidence level). In spite of the significant differences in infection intensities, aggregation parameters were similar between years The NBD parameter $k$ was high in different years, indicating a relatively uniform, unaggregated nature of the infestation of juveniles at different intensities (Table 2).

The surveys assumes that the infestation of salmon parr with Margaritifera margaritifera glochidia in the rivers of Karelia occurred in October and excystment takes place in September. Development of glochidia and excystment from the host seem to be mainly determined by temperature conditions in the region. Karelian rivers are generally characterized by a time of constant cooling after the water temperature has decreased to less than $10{ }^{\circ} \mathrm{C}$. 


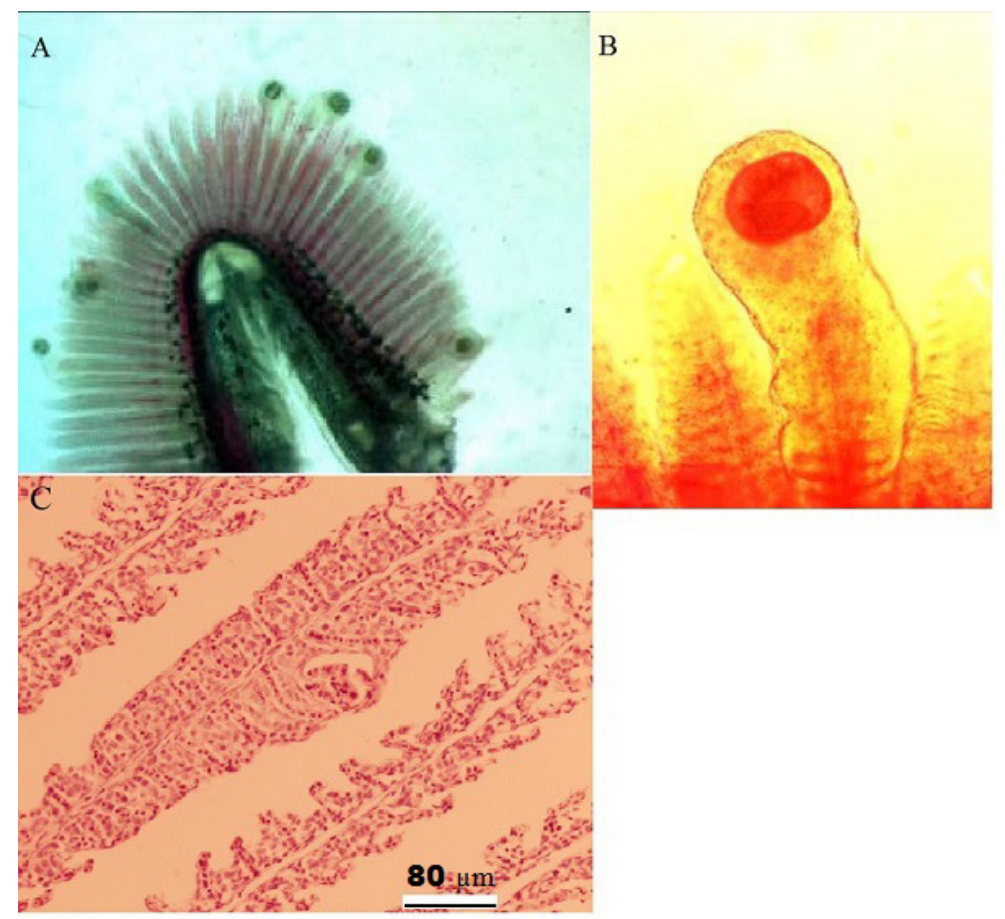

Fig. 2. Salmon gills with pearl mussel glochidia of parr from the Vuokinjoki River, 17.10.2013 (A - small magnification, binocular microscope, $\mathrm{B}$ - microscope with 10õ magnification, C - histological slide, Scale: $80 \mu \mathrm{m}$ ).
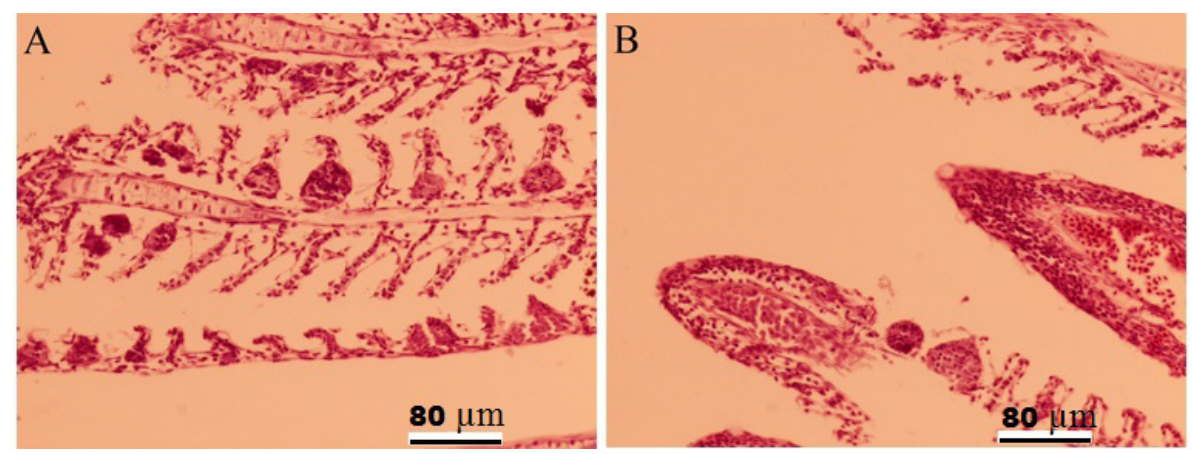

Fig. 3. Early phase of the salmon parr infection (08.10.2013) in the Syskyänjoki River. Scale: $80 \mu \mathrm{m}$.

In the rivers of the White Sea drainage basin - the Gridina and the Keret' - salmon were infected with non-encysted larvae at the beginning of October. In the Gridina River early in October, we found glochidia not only on salmon parr but also the gills of adult salmon and even on introduced pink salmon (Oncorhynchus gorbuscha, Walbaum, 1792), suggesting that a massive propagation of the pearl mussel was taking place.

A histological analysis allowed analyses of size differences of encysted glochidia during their parasitic phase of development on the gills of juvenile salmon in the Syskyänjoki River from October 2013 until May 2014 (Table 3). In October, the beginning of the infestation of fish was observed, as shown by the measured small size of glochidia and the low degree of size variation. The mean size of the encysted larvae was $57.4 \mu \mathrm{m}$ (Table 3), being similar to the size of glochidia that are freshly released from mussels. The identification of the initial phase of infection was additionally supported by the histological analysis: the triangle shape with sloping edges that is
Table 3. The mean diameter $(\mu \mathrm{m})$ statistical parameters of size of glochidia on the gills of salmon parr, and water temperature in the Syskyänjoki River. * - the size of glochidia significantly different $(p \leqslant 0.05)$ between October and December, $* *-$ the size of glochidia significantly different $(p \leqslant 0.05)$ between December and May.

\begin{tabular}{|l|c|c|c|}
\hline Parameter/Date & 08.10 .2013 & 05.12 .2013 & 07.05 .2014 \\
\hline N studied & 45 & 24 & 52 \\
Mean & 57.4 & $72.5^{*}$ & $108^{* *}$ \\
Std. error & 2.9 & 4.0 & 3.9 \\
Variance & 367.9 & 390.7 & 784.6 \\
Water temperature & 5.6 & 0.2 & 8.4 \\
$\left({ }^{\circ} \mathbf{C}\right)$ & & & \\
\hline
\end{tabular}

typical of glochidia freshly attaching (Nezlin et al., 1994) to a host (in the Gridina and the Keret' Rivers) was clearly visible (Figures 2, 3). Subsequently, formation of a cyst by the host epithelial tissues was observed which covered the glochidia 


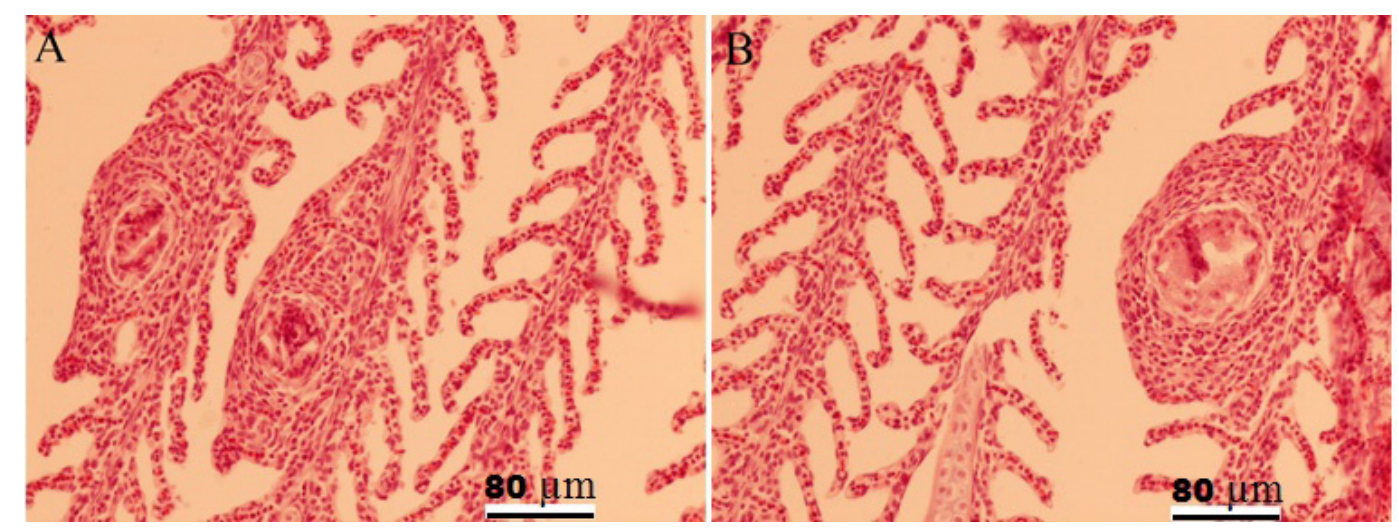

Fig. 4. A, B. Slow growing and diapausing glochidia of freshwater pearl mussel on the gills of salmon (05.12.2013) from the Syskyänjoki River. Scale: $80 \mu \mathrm{m}$. A - glochidia has a rounded completely embedded in gill tissue; B - the exterior (EL) and interior layers (IL) of the mantle, the muscle $(\mathrm{M})$ and gills $(\mathrm{G})$ of glochidia.

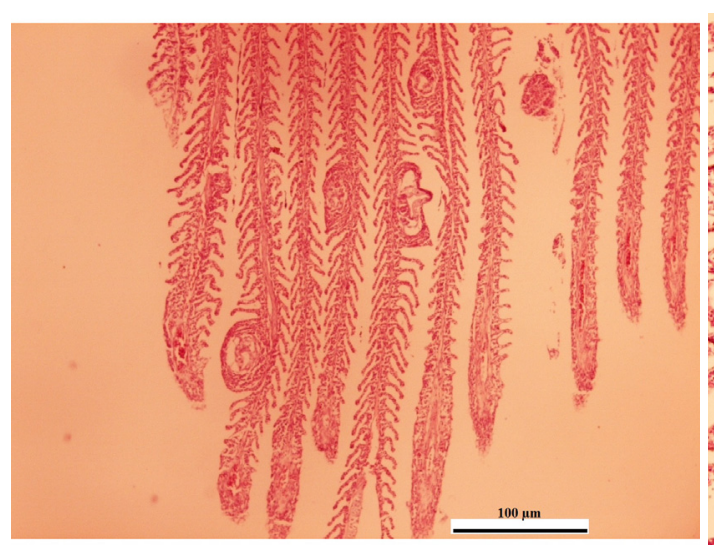

(a)

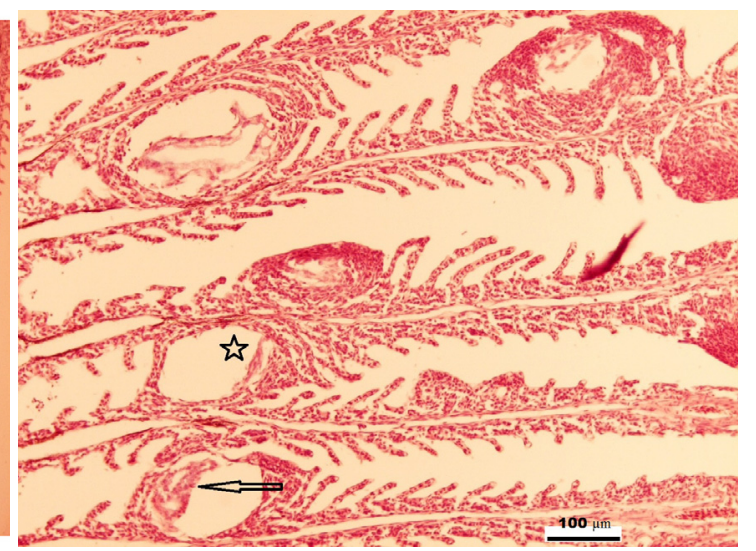

(b)

Fig. 5. A - Young metamorphosing pearl mussels (May 2014) on the gills of the host salmon from the Syskyänjoki River. Scale: $100 \mu \mathrm{m}$. B Cysts with young mollusks, empty cysts (asterisk) and cysts with non-viable glochidias (arrow) on the gills of salmon (May 2014) from the Syskyänjoki River. Scale: $100 \mu \mathrm{m}$.

with a thin layer of cells (Figure 3). It thus appears likely that the infestation began 5-6 days before sampling based on size and growth rate data. The negligible increase in the size of the encysted larvae showed that the growth of the glochidia was slow during more than 60 days of development in December (Table 3 ). In this period, the glochidia developed a rounded shape, and they were completely embedded in gill tissue and protected by the cyst (Figure 4A). Interestingly, some glochidia settled close to the base of the gill filament and to cysts formed by the epithelial cells of adjacent gills. Glochidia inside the cyst were growing and developing barely perceptible, and in addition to the exterior and interior layers of the mantle, the muscle, gills and the beginning of the formation of other organs were detected (Figure 4B). Infestation and ingrowth of glochidia in the Syskyänjoki River were observed in October at a water temperature of $5.6{ }^{\circ} \mathrm{C}$. Significant differences $(t=3.1, p \leqslant 0.05)$ were found between the mean sizes of glochidia in October and December (Table 3), indicating slow growth and development at low water temperatures. A previous study (Ieshko et al., 2014) described that the water temperature under the ice cover reached $1.4{ }^{\circ} \mathrm{C}$ when the river was frozen over, in November. Then, from December until March, the water temperature was less than $0.2{ }^{\circ} \mathrm{C}$ and ranged from 0.2 to $2.8^{\circ} \mathrm{C}$.

In the beginning of May 2014, after more than 150 days of development, significant increases in the mean size $(t=5.6$, $p \leqslant 0.05)$ of the encysted glochidia were found in comparison to size parameters of the attached glochidia in September and December (Table 3). Analyses of histological images showed that the metamorphosis of glochidia was almost complete, with close to completely metamorphosed juvenile mussels inside several cysts (Figure 5A). The water temperature was $2.8^{\circ} \mathrm{C}$ in April immediately following the spring breakup of ice on the Syskyänjoki River, and the average water temperature increased to $8.4^{\circ} \mathrm{C}$ in the begging of May (Ieshko et al., 2014). The measured average size (Table 3 ) of encysted young pearl mussels $(20 \%)$ on the gills of juvenile salmon in the studied river in May was relatively less than the size reported in a previous paper (Nezlin et al., 1994), where the encysted mollusc size was approximately $200 \mu \mathrm{m}$. In addition to cysts with young molluscs, we also observed empty cysts (5\%) and cysts with developmental disorders of glochidia - non-viable 


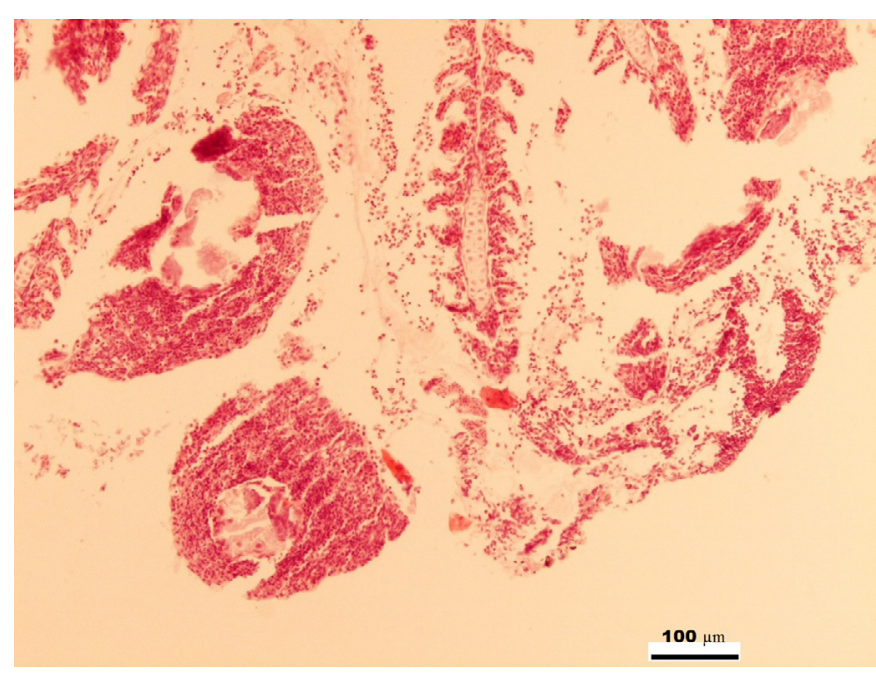

Fig. 6. Encysted and diapausing glochidia on the gills of salmon (26.10.2013) from the Vuokinjoki River. Scale: $100 \mu \mathrm{m}$.

glochidia (20\%) - in May 2014, i.e., when the mussels had completed their development on the host and dropped off (Figure 5B).

The relationship between salmon parr and glochidia was also evident from the results of the histological studies (Figures 2-6). Encysted glochidia on the gills of fish from the Syskyänjoki River in October and December differed in size, but no signs of cyst rejection were detected based on histology.

The average size of glochidia collected at the end of October (26th) from the Vuokinjoki River ranged from 140 to $187 \mu \mathrm{m}$. The glochidia from this river were metamorphosing, well developed and larger (Figure 6) in comparison to those on the gills of the juvenile fish from the Syskyänjoki River.

\section{Discussion}

The results of this study revealed that Atlantic salmon is the main host of the freshwater pearl mussel in the Karelian rivers surveyed. Salmon parr dominated in the examined mussel-populated rapid sections of the rivers, whereas trout was absent. This observation is in contrast to the host use of freshwater pearl mussel in central Europe, where brown trout is the preferred or only available host (Geist et al., 2006; Bauer, 1987).

Data from the rivers that we have surveyed point to a positive correlation between glochidial abundances and the size and weight of the parr. The correlation was most significant in the fish from the Keret' and the Gridina, where the infection was at an early stage. The fact that larger hosts can carry greater numbers of glochidia could be explained by their more intense respiration and greater water uptake as well as their greater gill surface area. The same size-dependent pattern within one age class of fish hosts was also previously observed in the pearl mussel-brown trout relationship (Taeubert et al., 2010). Surprisingly, despite their expected immunity, older hosts also carried great numbers of glochidia, which could be explained by their lack of previous contact with pearl mussel glochidia or an incomplete immunity. Yet, the role of YOY in the pearl mussel life cycle has always been crucial - while matching older age classes in the intensity of infection, YOY are more abundant and thus probably most important in terms of pearl mussel recruitment.

There is no general opinion about how pathogenic the glochidial infection is to fish. For instance, some researchers (Murphy, 1942; Meyers, Millemann, 1977; Karna, Millemann, 1978) reported mortalities among juvenile brown trout (Salmo trutta), Atlantic salmon (Salmo salar), rainbow trout (Oncorhynchus mykiss), coho salmon (O. kisutch) and chinook salmon (O. tchawytscha) experimentally infested with glochidia. Tauebert and Geist (2013) found that swimming performance and mortality in brown trout was increased at high rates of glochidial infection, probably decreasing the performance of highly infested fish in the wild. In contrast, Young and Williams (1984), as well as Young et al. (1987), found no mortalities or growth retardation in glochidia-infected trout. Similar data were obtained from experimental infestation of Atlantic salmon parr (Treasurer et al., 2006). Such differences can be explained by the occurrence of different host fish strains or different environmental conditions (e.g., temperature), which can all affect host-parasite interaction.

The population approach to the analysis of host-parasite relations between salmon parr and the freshwater pearl mussel must be used in studies on glochidial pathogenicity in which infection of juvenile fish is involved. Our results on the distribution parameters of glochidial abundances in the fish populations in the surveyed rivers (Table 1) were similar to previous data (Ieshko et al., 2009). The aggregated distribution of glochidial numbers (low numbers of parasites in most hosts, but some hosts with high numbers) likely facilitates the survival of the mussel larvae by increasing overall metamorphosis success on the one hand, and dispersal of larvae on the other hand, which both contribute to the survival of pearl mussel populations in the long-run. Low values of the NBD parameter $\mathrm{k}$, indicating a high degree of aggregation in the distribution of glochidia across the host population, indicate that the young fish were highly resistant to the infection. It has been demonstrated elsewhere (Crofton, 1971) that fish kill due to high parasitic infection rates may occur when the distribution parameter $\mathrm{k}$ exceeds a value of 3 .

One of the reasons for the stability of host-parasite relations between the pearl mussel and salmon parr likely is that the hosts are infected at lower water temperatures. In the northern range of the European pearl mussel distribution range, it has been found (Ziuganov et al., 1994) that the infestation of fish begins in autumn, when the water temperature falls below $10{ }^{\circ} \mathrm{C}$. It appears likely that the release of glochidia has been evolutionarily timed to the autumn temperature decrease. Experiments have demonstrated that low water temperature are linked with immune response intensity and that they enhance the success of encystment and metamorphosis in mussel larvae on fish hosts (Roberts and Barnhart, 1999; Taeubert et al., 2014). Our data are in line with findings demonstrating that low temperature inhibits immune responses in salmonids (Stewart et al., 2002) and can thus enhance the success of encystmnet and metamorphosis in mussel larvae on fish hosts (Roberts and Barnhart, 1999; Taeubert et al., 2014). 
Due to their remote location, the pearl mussel rivers draining into the White and Barents Sea are probably still among the most pristine pearl mussel rivers in the world, suggesting that they should have a high conservation priority. As evident from the Keret' River, the strong dependence on Atlantic salmon as a host fish and the complex density-dependent infestation patterns both suggest that maintaining population sizes of Atlantic salmon is the most crucial factor that needs to be considered in the conservation of those populations. In contrast to pearl mussel populations that exclusively depend on the less mobile brown trout, pearl mussel populations that depend on salmon are differentially affected because their host salmon populations are much more prone than brown trout to declines, which may be caused by overharvesting as well as by migration barriers in the rivers. Commercial as well as recreational fishing pressures on salmon populations in the area have already begun, and therefore the implementation of strict fisheries rules, as well as the enforcement of these rules is considered essential for the conservation of salmon and pearl mussel in this area. The inclusion of those rivers in a network of protected areas, the "Green belt Fennoscandia", is also likely to promote the conservation of those unique river systems.

\section{Conclusions}

Pearl mussel colonies in the studied rivers of Karelia (Northwest Russia) depend on Atlantic salmon parr as a host in their life cycle. We have demonstrated that where parr densities remained optimal, the rate of glochidial infection was relatively high. Encystment on the host in these areas lasts around eight months, with host infestation in October, and a completion of metamorphosis in the following May. As evident from our data, the stability of the host-parasite relationship with pearl mussel and Atlantic salmon is fragile and strongly temperature dependent. The timing of glochidial encystment, metamorphosis and release of juvenile mussels may be negatively affected by climate change, and a decrease of Atlantic salmon populations, particularly in the Keret' River.

Consequently, the conservation management of both freshwater pearl mussel and salmon needs to ensure high rates of recruitment on YOY fish, which can be achieved by sustainable fisheries management and the avoidance of parasite and disease introductions, as well as by ensuring high structural richness and quality of spawning and rearing habitats. In contrast to the situation of the endangered freshwater pearl mussel in most of Europe, where habitat degradation and siltation are the major problems (e.g., Geist, 2010), most of the rivers in Karelia are still in better condition, which needs to be safeguarded for the future.

Acknowledgements. The work was financially supported by the Federal budget of Russia (contract no. 0221-2014-0003, no. 02212014-0004 and no. 0221-2014-0005). This study was supported by funding from the RAS Presidium Basic Research Programme "The Living Nature: Present-day Condition and Development Problems" grant No 01201262107; The grant from the Russian Federation President "Leading Scientific School of Russia", Project "Ecological aspects of biochemical adaptations of aquatic organisms in high latitudes" NSH-1410.2014.4 (2014-2015); and under the agreement between the Institute of Biology of the Karelian Research Centre and the Finnish-Russian Working Group on Nature Conservation (2012-2013). The study was carried out at the Scientific Center of Collective Usage Platform of the Institute of Biology of the Karelian Research Centre of the Russian Academy of Sciences. The pearl mussel analysis was carried out with The Federal Supervisory Natural Resources Management Service, the State Nature Inspectorate Permit No 32 of March 23, 2012, and No 65 of April 2013.

\section{References}

Anderson R.M., 1982. Processes influencing the distribution of parasite numbers within host populations with special emphasis on parasite-induced host mortalities. Parasitology, 85, 373-398.

Anderson R.M., Whitefield P.J. and Dobson A.P., 1978. Experimental studies of infection dynamics: infection of the definitive host by cercaria of Transversotrema patialense. Parasitology, 77, 189-200.

Bauer G., 1987. Reproductive strategy of the freshwater pearl mussel Margaritifera margaritifera. J. Anim. Ecol., 56, 691-704.

Bauer G., 1992. Variation in the life span and size of the freshwater pearl mussel. J. Anim. Ecol., 61, 425-436.

Bern Convention, 1979. Convention of the conservation of European wildlife and natural habitat. Switzerland, Bern.

Bohlin T., 1984. Quantitative electrofishing for salmon and trout - views and recommendations. Information from Sotrattenslaboratoriet. Drottningholm, 4, pp. 1-33.

Bykhovskaya-Pavlovskaya I.E., 1985. Fish Parasites. Study Manual. Nauka, Leningrad [in Russian].

Crofton H.D., 1971a. A Quantitative Approach to Parasitism. Parasitology, 62, 179-194.

Crofton H.D., 1971b. A model of host-parasite relationships. Parasitology, 63, 343-364.

Cunjak R.A. and McGladdery S.E., 1991. The parasite-host relationship of glochidia (Mollusca: Margaritiferidae) on the gills of young-of-the-year Atlantic salmon (Salmo salar). Can. J. Zool., 69, 353-358.

Geist J., 2010. Strategies for the conservation of endangered freshwater pearl mussel (Margaritifera margaritifera L.): a synthesis of Conservation Genetics and Ecology. Hydrobiologia, 664, 69-88.

Geist J. and Auerswald K., 2007. Pysicochemical stream bed characteristics and recruitment of the freshwater pearl mussel. Freshwater Biol., 52, 2299-2316.

Geist J. and Kuehn R., 2008. Host-parasite interactions in oligotrophic stream ecosystems: The roles of life history strategy and ecological niche. Molec. Ecol., 17, 997-1008.

Geist J., Porkka M. and Kuehn R., 2006. The status of host fish populations and fish species richness in European freshwater pearl mussel (Margaritifera margaritifera) streams. Aquat. Conserv. Mar. Freshw. Ecosyst., 16, 251-266.

Grafena A. and Woolhouse M.E.J., 1993. Does the negative binomial distribution add up? Parasitology Today, 9, 475-477.

Hammer Ø., Harper D.A.T. and Ryan P.D., 2001. PAST: Paleontological Statistics Software Package for Education and Data Analysis. Palaeont. Electronica, 4, 9 p.

Hastie L.C. and Young M.R., 2001. Freshwater pearl mussel (Margaritifera margaritifera) glochidiosis in wild and farmed salmonid stocks in Scotland. Hydrobiologia, 45, 109-119.

Ieshko E.P., Shulman B.S., Shchurov I.L. and Barskaya Yu.Yu., 2008. Long-term changes in the juvenile Atlantic salmon (Salmo salar L.) epizootic in the Keret' River (White Sea drainage basin) caused by the invasion of Gyrodactylus salaris Malmberg, 1957. Parazitologija, 42, 486-496 [in Russian]. 
Ieshko E.P., Larsson B.M., Pavlov Yu.L., Barskaya Yu.Yu., Lebedeva D.I. and Novokhatskaya O.V., 2009. Population dynamics of the numbers of freshwater pearl mussel, Margaritifera margaritifera L., glochidia on juvenile salmonids in northern waterbodies. Biol. Bull., 36, 624-629.

IUCN Red List of Threatened Animals, Gland. Switzerland. IUCN, 1996.

Karna D.W. and Millemann R.E., 1978. Glochidiosis of salmonid fishes. III. Comparative susceptibility to natural infection with Margaritifera margaritifera (L.) (Pelycypoda: Margaritiferidae) and associated histopathology. J. Parasitol., 64, 528-537.

Meyers T.R. and Millemann R.E., 1977. Glochidiosis of salmonid fishes. I. Comparative susceptibility to experimental infection with Margaritifera margaritifera (L.) (Pelecypoda: Margaritiferidae). J. Parasitol., 63, 728-733.

Mikodina E.V., Sedova M.A. and Chmilevsky D.A. et al. 2009. Histology for ichthyologists: experience and advices. VNIRO, Moscow [in Russian].

Murphy G., 1942. Relationship of the freshwater mussel to trout in the Truckee River. California Fish and Game, 28, 89-102.

Nezlin L.P., Cunjak R.A., Zotin A.A. and Ziuganov V.V. 1994. Glochidium morphology of the freshwater pearl mussel (Margaritirefa margaritifera) and glochidiosis of Atlantic salmon (Salmo salar): a study by scanning electron microscopy. Can. J. Zool., 72, 15-21.

Pavlov Y.L. and Ieshko E.P., 1986. A distribution model of the number of parasites. Rep. Acad. Sci. USSR, 289, 746-748.

Red Data Book of East Fennoscandia. Helsinki, 1998, pp. 291-293.

Red Data Book of Karelia. Petrozavodsk, Karelia, 2007, pp. 307-308 [in Russian].

Red Data Book of the Russian Federation (Animals), 2001. Astrel, Moscow, pp. 61-62 [in Russian].

Roberts A.D. and Barnhart M.C., 1999. Effect of temperature, pH, and $\mathrm{CO}_{2}$ on transformation of the glochidia of Anadonta suborbiculata on fish host and in vitro. J. North Am. Benthol. Soc., 18, 477-487.
Rozsa L., Reiczigel J. and Majoros G., 2000. Quantifying parasites in samples of hosts. J. Parasitol., 86, 228-232.

Stewart W.A., Murray A.L. and Pascho R.J., 2002. Effects of rearing temperature on immune functions in sockeye salmon (Oncorhynchus nerka). Fish Shellfish Immunol., 12, 303-334.

Taeubert J.E. and Geist J., 2013. Critical swimming speed of brown trout (Salmo trutta) infested with freshwater pearl mussel (Margaritifera margaritifera) glochidia and implications for artificial breeding of an endangered mussel species. Parasitol. Res., 112, 1607-1613.

Taeubert J.E., Denic M., Gum B., Lange M. and Geist J., 2010. Suitability of different salmonid strains as hosts for the endangered freshwater pearl mussel (Margaritifera margaritifera L.). Aquat. Conserv. Mar. Freshw. Ecosyst., 20, 728-734.

Taeubert J.E., El-Nobi G. and Geist J., 2014. Effects of water temperature on the larval parasitic stage of the thick-shelled river mussel (Unio crassus). Aquat. Conserv. Mar. Freshw. Ecosyst., 24, 231-237.

Treasurer J.W., Hastie L.C., Hunter D., Duncan F. and Treasurer C.M., 2006. Effects of Margaritifera margaritifera glochidial infection on performance of tank-reared Atlantic salmon (Salmo salar). Aquaculture, 256, 74-79.

Young M.R. and Williams J.C., 1984. The reproductive biology of the freshwater pearl mussel. I. Field studies. Archive Hydrobiol., 99, 405-422.

Young M.R., Purser J. and Al-Mousawi B., 1987. Infection and successful reinfection of Brown trout Salmo trutta (L.) with glochidia of Margaritifera margaritifera (L.). Am. Malacol. Bull., $5,125-128$.

Zippin C., 1956. An evaluation of removal method of estimating animal populations. Biometrics, 12, 163-169.

Ziuganov V., Zotin A., Nezlin L. and Tretiakov V., 1994. The Freshwater Pearl Mussels and their Relationships with Salmonid Fish. VNIRO. Russian Federal Research Institute of Fisheries and Oceanography, Moscow [in Russian].

Cite this article as: E.P. Ieshko, J. Geist, S.A. Murzina, A.E. Veselov, D.I. Lebedeva and V.V. Ziuganov, 2016. The characteristics of the infection of juvenile Atlantic salmon with glochidia of the freshwater pearl mussel in rivers of Northwest Russia. Knowl. Manag. Aquat. Ecosyst., 417, 6 . 